Saudi Journal of Biomedical Research

Abbreviated Key Title: Saudi J Biomed Res ISSN 2518-3214 (Print) |ISSN 2518-3222 (Online)

\title{
Extracts from Commelina diffusa Protect Against Gentamicin-Induced Nephrotoxicity in Wistar Rats
}

\author{
Serges Kamdem Djoko ${ }^{1}$, Moise Legentil Nchouwet $^{1}$, Sylviane Laure Poualeu Kamani ${ }^{1}$, Norbert Kodjio ${ }^{2}$, Albert \\ Kamanyi $^{1}$, Sylvie Lea Wansi Ngnokam ${ }^{1 *}$ \\ ${ }^{1}$ Research Unit of Animal Physiology and Phytopharmacology, Department of Animal Biology, Faculty of Science, University of Dschang, PO Box 67 \\ Dschang, Cameroon \\ ${ }^{2}$ Department of Biochemistry, Faculty of Sciences, University of Dschang, Cameroon
}

DOI: $10.36348 /$ sjbr.2020.v05i04.007

| Received: 04.04.2020 | Accepted: 11.04.2020 | Published: 24.04 .2020

*Corresponding author: Sylvie Lea Wansi Ngnokam

Abstract

This study aimed to evaluate the effects of aqueous and methanolic extracts of Commelina diffusa on gentamicin induced-nephrotoxicity in rats. Nephrotoxicity was induced by intraperitoneal injection of gentamicin $(80 \mathrm{mg} / \mathrm{kg}) \mathrm{for} 10$ days. Simultaneous, extracts were administered at doses of 100 and $200 \mathrm{mg} / \mathrm{kg}$. Silimaryn $(100 \mathrm{mg} / \mathrm{kg}) \mathrm{was} \mathrm{used} \mathrm{as}$ reference drug. At the end of the experimental period, body weight, kidney weight, urine output, biochemical and antioxidants parameters were evaluated; kidney tissues were also examined. Results showed that gentamicin induced nephrotoxicity confirmed by a significant ( $\mathrm{p}<0.05$ to $\mathrm{p}<0.001)$ increased in serum urea, sodium and creatinine levels, and a significant $(\mathrm{P}<0.05)$ decreased of urine creatinine level in negative control group. In the same group, the activities of superoxide dismutase and catalase, and the levels of gluthation and serum protein were significantly decreased while malondialdehyde level was increased compared to normal control. Aqueous and methanolic extracts of $C$. diffusa significantly reversed all the altered parameters. Histopathological examination of kidney tissues revealed that aqueous extract of $C$. diffusa at dose of $200 \mathrm{mg} / \mathrm{kg}$ repaired the renal damage induced by gentamicin. In conclusion, aqueous and methanolic extracts of $C$. diffusa possess nephroprotective effects.

Keywords: Gentamicin, nephrotoxicity, Commelina diffusa, nephroprotective activities.

Copyright @ 2020: This is an open-access article distributed under the terms of the Creative Commons Attribution license which permits unrestricted use, distribution, and reproduction in any medium for non-commercial use (NonCommercial, or CC-BY-NC) provided the original author and source are credited.

\section{INTRODUCTION}

The large blood flows of the kidney and its ability to extract and concentrate hydrosoluble toxic molecules, prone to kidney damage [1]. Renal failure represents one of the major problems in the world, and renal damage is very common since kidney excretes toxic substances. The Global Burden of Disease 2015 study estimated that, in 2015, 1.2 million people died from kidney failure, an increase of $32 \%$ since 2005 [2]. The kidney damage is usually a consequence of tubular obstruction caused by cell swelling or debris deposition [3]. Several studies have shown that toxic substances can damage various cell types in kidney.

Gentamicin (GM) is an aminoglycoside antibiotic with a wide spectrum of activities vastly used in the treatment of Gram-negative bacterial infections [4]. But its usefulness is limited due to its serious side effects such as nephrotoxicity [5]. The central aspect of GM nephrotoxicity is tubular cytotoxicity. This cytotoxicity is related to apoptosis as well as necrosis of tubular epithelial cells [6]. One of the principal elements that intermediates gentamicin-induced renal impairment is reactive oxygen species (ROS) [7]. ROS produce cellular injuries and tissue death via several mechanisms including peroxidation of membrane lipids; protein denaturation and Deoxyribonucleic acid (DNA) damage [8].

Herbs have been used as alternative medicines in various diseases [9]. Commelina diffusa is a pantropical herbaceous medicinal plant in the dayflower family [10]. It is widely distributed throughout Bangladesh and other South Asian countries and in Africa. In Chinese traditional medicine it is used to reduce swelling and inflammation [11]. In Asia, Africa and America it is commonly used to treat urinary infections, diarrhea, hemorrhoids, enteritis, eye irritation, conjunctivitis, ophthalmia, laryngitis, sore throats, otitis media and nose bleeding [12,13]. Throughout Latin America the plant parts are used in dermatitis and Burns [14]. Phytochemical studies have shown that $C$. diffusa contains high proportion of 
flanonoids, alkaloids, phytosterols and triterpernoids $[15,16]$. Flavonoids are known to counteract the oxidation pressures caused by toxic compounds in the human body and work to neutralize them. However, there is no pharmacological study on the possible nephroprotective effect of Commelina diffusa against GM induced renal damage in rats. Therefore, the present study was conducted to evaluate the effects of aqueous and methanolic extracts of $C$. diffusa in gentamin-induced nephrotoxicity in Wistar rats intoxicated.

\section{MATERIALS AND METHODS Drugs and chemicals}

Different solvents and kits for biochemical assay were purchased from Geochim laboratory Ltd, Bafoussam, Cameroon. Silymarin was purchased from Sigma Aldrich, Saint Louis, USA. Gentamicin was purchased from a local pharmacy store.

\section{Plant material}

The whole plant was collected in Dschang, (West Cameroon) in February (2017) and authenticated at the National Herbarium of Cameroon by comparison to the voucher specimen number SRFC/35189.

\section{Preparation of plant extracts}

The whole plant was dried at room temperature away from sun light and ground into a coarse powder using an electric blender. This powder was used to prepare the aqueous and methanolic extracts.

\section{Aqueous extract preparation}

Five hundred grams $(500 \mathrm{~g})$ of powder of $C$. diffusa were mixed with $5 \mathrm{~L}$ of distilled water and the mixture was boiled for $40 \mathrm{~min}$. After cooling, the solution was filtered with a whatmann paper $\mathrm{N}^{\circ} 1$. The filtrate was evaporated in the oven at $45^{\circ} \mathrm{C}$ to obtain 59 g of crude extract.

\section{Methanolic extract preparation}

Four hundred grams (400 g) of powder were macerated in $3 \mathrm{~L}$ of methanol for $24 \mathrm{~h}$. The macerate obtained was filtrated and then evaporated at $65^{\circ} \mathrm{C}$ using rotary evaporator to obtain $13.6 \mathrm{~g}$ of methanolic extract.

\section{Animals}

Male Wistar albino rats aged 10 to 12 weeks and weighing between $200 \mathrm{~g}$ and $220 \mathrm{~g}$ were raised in the Animal House of Department of Animal Biology of Faculty of Science, University of Dschang, Cameroon under natural temperature and normal day/night cycle. They received standard food and water ad libitum. All animal procedures were conducted with strict adherence to the NIH Guide for the care and use of laboratory animas (NIH Publication 85-23 Rev. 1985).

\section{Experimental design and procedures}

Forty two (42) rats were divided into seven groups of six rats each: group 1 or normal control received distilled water; group 2 or negative control received distilled water; group 3 or positive control received silymarin (100 $\mathrm{mg} / \mathrm{kg} /$ day $)$; groups 4 and 5 were treated with aqueous extract of $C$. diffusa (AECD) at doses of 100 and $200 \mathrm{mg} / \mathrm{kg}$ respectively and groups 6 and 7 were treated with methanolic extract of MECD C. diffusa at same doses. All these treatment were administered daily for 10 consecutive days. During the ten days the rats of group 1 were injected with saline solution while all other groups received intraperitoneal injection of gentamicin $(80 \mathrm{mg} / \mathrm{kg})$.

On day $11^{\text {th }}$, each animal were kept in individual metabolic cages for 24 hours for urine collection.

\section{Blood sample collection and biochemical analysis}

At the end of the experiment, animals were anesthetized by intrapertoneal injection of Diazepam ( 5 $\mathrm{mg} / \mathrm{kg}$ ) followed by Ketamine hydrochloride (50 $\mathrm{mg} / \mathrm{kg}$ ). The abdominal cavity was opened; blood samples were collected by catheterism of abdominal artery in non-heparinized test tubes and were centrifugated at $3000 \mathrm{rpm}$ for $15 \mathrm{~min}$. Serum obtained was stored at $-20^{\circ} \mathrm{C}$ until it was used for the estimation of electrolytes $\left(\mathrm{Na}^{+}, \mathrm{K}^{+}\right.$and $\left.\mathrm{Cl}^{-}\right)$, urea, creatinine, and total protein. Creatinine was also measure in the urine. After blood collection sample, kidneys were collected, blotter dried, weighed. The right kidney was excised transferred into $10 \%$ neutral buffered formalin for histological examination, while the left kidney was used for antioxidant studies.

\section{Antioxidant parameters estimations}

Left kidney excised was homogenized in cold $50 \mathrm{mM}$ potassium phosphate buffer $(\mathrm{pH} 7.4)$ at a concentration $15 \% \quad(\mathrm{w} / \mathrm{v})$ using homogenizer. The unbroken cells and cell debris were removed by centrifugation at $1000 \mathrm{rpm}$ for $10 \mathrm{~min}$ using a refrigerated centrifuge. After this stage, the homogenate was subjected to centrifugation (6000 rpm for $15 \mathrm{~min}$ ) and the supernatant was used for the estimation of gluthation (GSH), malondialdehyde (MDA) and the activities of superoxide dismutase (SOD) and catalase (CAT).

\section{Histological study}

Kidney tissues were taken from animals after sacrificed. The tissues were washed with ice-cold saline solution to remove blood, fixed immediately in $10 \%$ neutral buffered formalin, dehydrated in different grades of alcohol, embedded in paraffin wax, sectioned at 4-6 $\mu \mathrm{m}$ thick, stained with Haematoxylin and Eosin and cleared in xylene; then examined microscopically. 


\section{STATISTICAL ANALYSIS}

Results were expressed as the Mean \pm Standard Error Mean (S.E.M.). Data were analyzed by one way Analysis of Variance (ANOVA) using Graph Pad Prism versus 5.0. The means were separated and compared by Tukey post-test. $\mathrm{p}<0.05$ was considered as statistical significant.

\section{RESULTS}

Effects of AECD and MECD on body weight, kidney weight and urine volume
Ten days injection of GM $(80 \mathrm{mg} / \mathrm{kg})$ significantly reduced $(\mathrm{p}<0.01)$ the body weight and increased $(p<0.001)$ the relative kidney weight of rats. C. diffusa extracts and silymarin significantly $(\mathrm{p}<0.5$; $0.01 ; 0.001)$ reversed these altered parameters (Table1).

Rats of negative control group showed nonsignificant increase of urine volume when compared to normal control group; while that of rats treated with $C$. diffusa extracts at dose of $200 \mathrm{mg} / \mathrm{kg}$ significantly increased.

Table-1: Effect of AECD and MECD on body weight, kidney weight and urine volume

\begin{tabular}{|l|c|c|c|}
\hline Group/Treatment (mg/kg) & Mean body weight $(\mathbf{\%})$ & $\begin{array}{c}\text { Relative Kidney weight } \\
(\mathbf{g} / \mathbf{1 0 0 g} \text { bw) }\end{array}$ & $\begin{array}{c}\text { Urine output volume } \\
(\mathbf{m l} / \mathbf{1 0 0 g} \text { bw) }\end{array}$ \\
\hline Normal Control & $123.00 \pm 2.42$ & $0.32 \pm 0.00$ & $2.30 \pm 0.19$ \\
\hline Negative control (GM) & $96.39 \pm 0.60^{\mathrm{c}}$ & $0.49 \pm 0.07^{\mathrm{c}}$ & $4.07 \pm 0.56$ \\
\hline Silymarin 100 + GM & $112.40 \pm 1.40^{\gamma}$ & $0.36 \pm 0.01^{\gamma}$ & $3.05 \pm 0.55$ \\
\hline EACD 100 + GM & $106.10 \pm 0.79^{\beta}$ & $0.35 \pm 0.03^{\gamma}$ & $4.81 \pm 0.88$ \\
\hline EACD 200 + GM & $104.71 \pm 1.36^{\alpha}$ & $0.38 \pm 0.01^{\beta}$ & $5.78 \pm 1.28^{\mathrm{b}}$ \\
\hline MECD100 + GM & $108.40 \pm 2.24^{\gamma}$ & $0.34 \pm 0.02^{\gamma}$ & $4.10 \pm 0.55$ \\
\hline MECD 200 + GM & $106.20 \pm 1.62^{\beta}$ & $0.33 \pm 0.02^{\gamma}$ & $5.28 \pm 0.88^{\mathrm{a}}$ \\
\hline
\end{tabular}

Values are represented as Mean \pm S.E.M. ${ }^{c} \mathrm{p}<0.001$ : significant difference compared to normal control group; $\alpha \mathrm{p}<0.05,{ }^{\beta} \mathrm{p}<0.01$, ${ }^{\gamma} \mathrm{P}<0.001$ : significant difference compared to negative control group. $\mathrm{AECD}=$ Aqueous extract of Commelina diffusa, $\mathrm{MECD}=$ Methanolic extract of Commelina diffusa $. \mathrm{GM}=$ Gentamicin.

Effects of the AECD and the MECD on serum parameters

As shown in Table 2, GM significantly $(\mathrm{p}<0.05$ to $\mathrm{p}<0.001)$ increased the serum creatinine and serum urea level while the urine creatinine level was significantly reduced. MECD (200 mg/kg) and silymarin significantly $(\mathrm{p}<0.001)$ decreased the serum creatinine and urea level. Otherwise, extracts significantly $(\mathrm{p}<0.05$ to $\mathrm{p}<0.001)$ increased the urine creatinine level compared to the negative control group. They also significantly increased $(p<0.05)$ the creatinine clearance, reduced by daily injection of GM.

Table-2: Effects of AECD and MECD on serum parameters

\begin{tabular}{|c|c|c|c|c|}
\hline $\begin{array}{c}\text { Group/Treatment } \\
(\mathbf{m g} / \mathbf{k g})\end{array}$ & $\begin{array}{c}\text { Serum creatinine } \\
(\mathbf{m g} / \mathbf{d l})\end{array}$ & $\begin{array}{c}\text { Urine creatinine } \\
(\mathbf{m g} / \mathbf{d l})\end{array}$ & $\begin{array}{c}\text { Creatinine } \\
\text { clearance } \\
(\mathbf{m l} / \mathbf{m i n})\end{array}$ & $\begin{array}{c}\text { Serum urea } \\
(\mathbf{m g} / \mathbf{m l})\end{array}$ \\
\hline Normal Control & $163.3 \pm 15.85$ & $554.41 \pm 67.71$ & $0.05 \pm 0.01$ & $98.69 \pm 3.71$ \\
\hline Negative control & $300 \pm 24.22^{\mathrm{c}}$ & $182.42 \pm 21.971^{\mathrm{c}}$ & $0.023 \pm 0.00$ & $142.20 \pm 13.63^{\mathrm{b}}$ \\
\hline Silymarin 100 + GM & $103.30 \pm 24.45^{\gamma}$ & $564.00 \pm 13.62^{\gamma}$ & $0.20 \pm 0.12$ & $120.50 \pm 5.89$ \\
\hline EACD 100 + GM & $226.70 \pm 37.24$ & $596.80 \pm 50.97^{\gamma}$ & $0.052 \pm 0.01$ & $94.64 \pm 4.54^{\gamma}$ \\
\hline EACD 200 + GM & $253.30 \pm 16.06$ & $462.41 \pm 78.74^{\alpha}$ & $0.08 \pm 0.02$ & $99.00 \pm 6.42^{\beta}$ \\
\hline MECD100 + GM & $293.30 \pm 12.29$ & $513.60 \pm 27.56^{\beta}$ & $0.05 \pm 0.01$ & $95.20 \pm 4.46^{\beta}$ \\
\hline MECD 200 + GM & $186.70 \pm 15.20^{\gamma}$ & $396.00 \pm 57.90$ & $0.07 \pm 0.01$ & $90.66 \pm 6.67^{\gamma}$ \\
\hline
\end{tabular}

Values are represented as Mean \pm S.E.M. ${ }^{b} \mathrm{p}<0.01,{ }^{c} \mathrm{p}<0.001$ : significant difference compared to normal control group; ${ }^{\alpha} \mathrm{p}<0.05$,

${ }^{\beta} \mathrm{p}<0.01 ;{ }^{\gamma} \mathrm{p}<0.001$, significant difference compared to negative control group. AECD $=$ Aqueous extract of Commelina diffusa, MECD=Methanolic extract of Commelina diffusa. $\mathrm{GM}=$ Gentamicin

\section{Effect of AECD and MECD on serum electrolytes}

Serum concentration of sodium significantly $(\mathrm{p}<0.05)$ increased after injection of GM $(80 \mathrm{mg} / \mathrm{kg})$. Treatment with AECD $(100 \mathrm{mg} / \mathrm{kg})$ and MECD (200 $\mathrm{mg} / \mathrm{kg})$ significantly $(\mathrm{p}<0.01)$ reduced the sodium level of rats when compared to negative control group. GM $(80 \mathrm{mg} / \mathrm{kg})$ did not cause any significant change on serum potassium and chloride level. However MECD $(100 \mathrm{mg} / \mathrm{kg})$ significantly $(\mathrm{p}<0.05)$ reduced the chloride level of rats compared to control groups (Table 3 ). 
Table-3: Effect of AECD and MECD on serum electrolytes

\begin{tabular}{|c|c|c|c|}
\hline Group/Treatment (mg/kg) & $\begin{array}{c}\text { Serum sodium } \\
(\mathbf{M E q} / \mathbf{L})\end{array}$ & $\begin{array}{c}\text { Serum potassium } \\
(\mathbf{M E q} / \mathbf{L})\end{array}$ & $\begin{array}{c}\text { Serum chloride } \\
(\mathbf{M E q} / \mathbf{L})\end{array}$ \\
\hline Normal Control & $152.30 \pm 0.33$ & $4.80 \pm 0.28$ & $112.70 \pm 0.33$ \\
\hline Negative control (GM) & $154.00 \pm 0.0^{\mathrm{a}}$ & $4.25 \pm 0.08$ & $111.80 \pm 0.91$ \\
\hline Silymarin 100 + GM & $151.30 \pm 0.33^{\mathrm{a}}$ & $4.46 \pm 0.27$ & $112.00 \pm 0.51$ \\
\hline EACD 100 + GM & $150.50 \pm 0.5^{\gamma \mathrm{b}}$ & $4.12 \pm 0.28$ & $109.00 \pm 1.39$ \\
\hline EACD 200 + GM & $153.21 \pm 0.47$ & $4.20 \pm 0.23$ & $113.00 \pm 0.81$ \\
\hline MECD100 + GM & $152.80 \pm 0.16$ & $4.33 \pm 0.59$ & $105.50 \pm 1.70^{\alpha .6}$ \\
\hline MECD 200 + GM & $150.71 \pm 0.81^{\gamma \mathrm{a}}$ & $4.53 \pm 0.25$ & $109.30 \pm 1.97$ \\
\hline
\end{tabular}

Values are represented as Mean \pm S.E.M. ${ }^{a} \mathrm{p}<0.05 ;{ }^{b} \mathrm{p}<0.01$ : significant difference compared to normal control group; ${ }^{\alpha} \mathrm{P}<0.05$; ${ }^{\gamma} \mathrm{P}<0.001$, significant difference compared to negative control group. $\mathrm{AECD}=$ Aqueous extract of Commelina diffusa, $\mathrm{MECD}=$ Methanolic extract of Commelina diffusa. $\mathrm{GM}=$ Gentamicin $(80 \mathrm{mg} / \mathrm{kg})$.

Effect of AECD and MECD on antioxidant parameters

The mean values of MDA, SOD, CAT, GSH and TP obtained at the end of the experimental period are recorded in Table 4.

These results showed that daily injection of GM $(80 \mathrm{mg} / \mathrm{kg})$ significantly $(\mathrm{p}<0.01)$ increased the levels of MDA in the kidney tissue of rats. Treatment of rats with $C$. diffusa and silymarin significantly $(\mathrm{P}<0.001)$ decreased the level of MDA compared to negative control group.

Animals of negative control group exhibited a significant decrease $(\mathrm{p}<0.05)$ in SOD and CAT activities in renal tissue when compared to their corresponding normal control values. Aqueous and methanolic extracts of $C$. diffusa at both doses and silymarin $(100 \mathrm{mg} / \mathrm{kg})$ significantly $(\mathrm{p}<0.05 ; \mathrm{p}<0.001)$ increased the CAT and SOD activities when compared to the nephrotoxic group. Only the AECD (100 mg/kg) significantly $(\mathrm{p}<0.05)$ increased the activity of SOD in renal tissue of rats when compared to the negative control group.

Significant increased $(\mathrm{p}<0.05)$ of GSH was obtain only with rats treated with silymarin when compare to the negative control group.

GM $(80 \mathrm{mg} / \mathrm{kg})$ injection reduced total proteins of rats. AECD $(100 \mathrm{mg} / \mathrm{kg})$ and the MECD $(100 \mathrm{mg} / \mathrm{kg})$ showed significant increase of TP when compare to the negative group.

Table-4: Effects of the AECD and the MECD on antioxidant parameters in Gentamicin-induced nephrotoxic albino rats

\begin{tabular}{|c|c|c|c|c|c|}
\hline $\begin{array}{c}\text { Group/Treatment } \\
(\mathbf{m g} / \mathbf{k g})\end{array}$ & $\begin{array}{c}\text { GSH }(\boldsymbol{\mu m o l} / \mathbf{g} \\
\text { tissue) }\end{array}$ & $\begin{array}{c}\text { MDA (mol/mg } \\
\text { tissue) }\end{array}$ & $\begin{array}{c}\text { CAT } \\
(\mathbf{m o l} / \mathbf{m g} \\
\text { tissue) }\end{array}$ & $\begin{array}{c}\text { SOD (U/mg } \\
\text { protein) }\end{array}$ & $\begin{array}{c}\text { Total Protein } \\
(\mathbf{g} / \mathbf{d l})\end{array}$ \\
\hline Normal control & $4.86 \pm 0.06$ & $0.14 \pm 0.02$ & $0.17 \pm 0.00$ & $2.05 \pm 0.02$ & $7.72 \pm 1.10$ \\
\hline Negative control & $3.51 \pm 0.22$ & $0.23 \pm 0.02^{\mathrm{b}}$ & $0.11 \pm 0.01^{\mathrm{a}}$ & $1.99 \pm 0.00^{\mathrm{a}}$ & $2.10 \pm 0.18$ \\
\hline Silymarin 100 + GM & $5.23 \pm 0.04^{\alpha}$ & $0.10 \pm 0.00^{\gamma}$ & $0.19 \pm 0.01^{\gamma}$ & $2.01 \pm 0.00$ & $10.5 \pm 3.6$ \\
\hline AECD 100 + GM & $4.69 \pm 0.45$ & $0.12 \pm 0.01^{\gamma}$ & $0.16 \pm 0.01^{\alpha}$ & $2.16 \pm 0.07^{\alpha}$ & $21.92 \pm 6.66^{\beta}$ \\
\hline AECD 200 + GM & $4.40 \pm 0.02$ & $0.12 \pm 0.01^{\gamma}$ & $0.16 \pm 0.01^{\alpha}$ & $2.00 \pm 0.00$ & $6.14 \pm 0.79$ \\
\hline MECD 100 + GM & $4.60 \pm 0.68$ & $0.10 \pm 0.01^{\gamma}$ & $0.17 \pm 0.01^{\alpha}$ & $2.00 \pm 0.00$ & $16.97 \pm 2.60^{\alpha}$ \\
\hline MECD 200 + GM & $4.78 \pm 0.30$ & $0.11 \pm 0.02^{\gamma}$ & $0.19 \pm 0.01^{\gamma}$ & $2.00 \pm 0.00$ & $12.03 \pm 2.66$ \\
\hline
\end{tabular}

Values are represented as Mean \pm S.E.M. ${ }^{b} \mathrm{p}<0.01$ : significant difference compared to normal control group; ${ }^{\alpha} \mathrm{p}<0.05,{ }^{\beta} \mathrm{p}<0.01$, ${ }^{\gamma} \mathrm{p}<0.001$ : significant difference compared to negative control group. $\mathrm{AECD}=$ Aqueous extract of Commelina diffusa, MECD=Methanolic extract of Commelina diffusa. $\mathrm{GM}=$ Gentamicin $(80 \mathrm{mg} / \mathrm{kg})$.

\section{Histological examination of the kidney tissues}

The renal architecture is normal in the normal control group of rats with renal normal cortex showing normal corpuscle and tubules with little congestion of cortical blood vessels (Fig.1.Control). In nephrotoxic group, renal architecture showed cell damage characterized by leucocytes infiltration (I), widening of the Bowman's capsule, tubular clarification (TC) and mesangial expansion (ME) (Fig. 1.GM). In the AECD groups leucocytes infiltration (I) were observed (Fig.1. AE 100) whereas in the MECD groups the tubular clarification (TC), inflammation and minimal mesangial expansion (ME) were observed. In Silymarin treated rats the renal architecture appeared to be normal (Fig.1.SIL). 


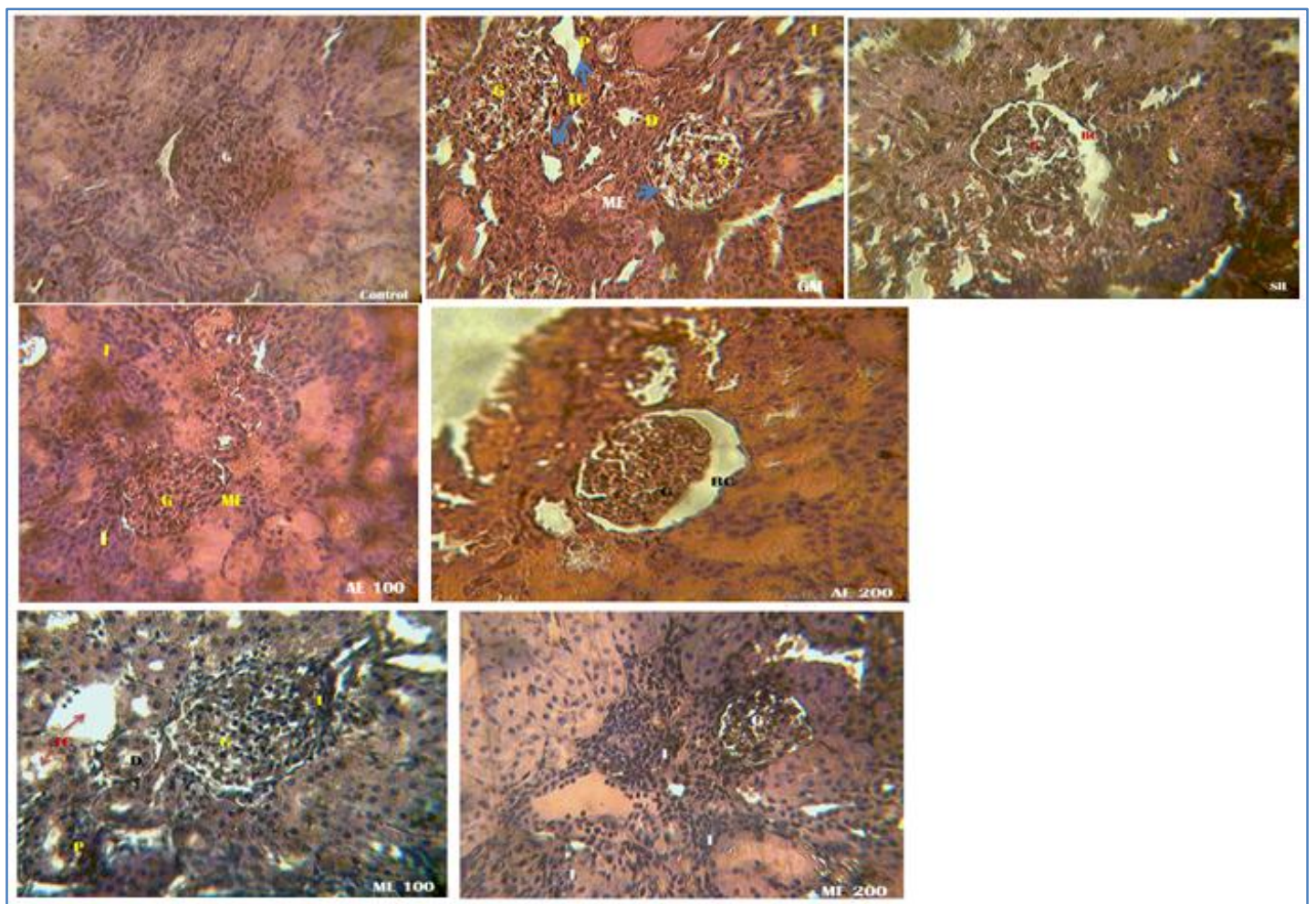

Fig-1: Histological images of kidney of rats pretreated with Commelina diffusa extracts and silymarin in gentamicin-induced nephrotoxicity (200x).

$\mathrm{I}=$ Infiltration of leucocytes (Inflammation), $\mathrm{G}=\mathrm{Glomerulus}, \mathrm{BC}=$ Bowman's capsule, $\mathrm{D}=$ Distal convoluted tubule, $\mathrm{P}=$ Proximal convoluted tubule, $\mathrm{ME}=$ Mesangial Expansion, $\mathrm{TC}=$ tubular clarification.

\section{DISCUSSION}

GM is an aminoglycoside antibiotic with a wide spectrum of activities. It is vastly used in the treatment of Gram-negative bacterial infections [4]. However, it is one of the leading causes of druginduced nephrotoxicity [7]. The present study was undertaken to evaluate the effects of AECD and MECD on rat model of gentamicin-induced nephrotoxicity. This is characterized by elevated levels of urea, creatinine and uric acid in plasma, as well as severe proximal tubular necrosis and renal failure [17].

A number of experimental studies in rats have shown that the GM toxicity is related to the loss of body weight and the increase of kidney weight. The body weight loss may be attributed to dehydration and anorexia due to acidosis following gentamicin administration [18] while an increase of the kidney weight might be attributed to inflammation [7]. In the present study, intraperitoneal injection of GM $(80 \mathrm{mg} / \mathrm{kg})$ significantly $(\mathrm{p}<0.001)$ decreased the body weight of rats and increased the relative kidney weight. Similar results were obtained by Chinnala et al. [19]. It has also been observed in this study that the GM has increased the urine volume of rats. It is well known that intraperitoneal injection of GM decreased the reabsorption of water in the proximal convoluted tubule leading to dehydration. Therefore, the decrease of body weight could be due to dehydration. Treatment with AECD and MECD significantly $(p<0.001)$ increased the body weight of rats. The improvement in growth could be attributed to the nutritive value of $C$. diffusa extracts. Indeed, Chullanandana [20] has shown that this plant contains high protein content.

Serum creatinine and urea are known as biomarkers to detect the early phase of renal damage and chronic renal damage [21]. Creatinine derived from endogenous sources by tissue creatinine breakdown and its clearance enables a quite good estimation of the glomerular filtration rate (GFR) [22]. The concentration of creatinine is elevated when GFR is markedly decreased in renal pathies [23]. Urea is the nitrogen containing end product of protein catabolism. Its concentration begins to increase only after parenchymal tissue injury [24]. The nephrotoxicity of GM is often associated with the elevation of blood urea and serum creatinine [25]. These finding showed that daily injection of GM $(80 \mathrm{mg} / \mathrm{kg})$ for ten days significantly $(\mathrm{p}<0.01)$ increased serum creatinine and urea levels and significantly decreased urine creatinine concentration. In addition, creatinine clearance was considerably reduced. Similar results were obtained by Hamad et al. [26]. The significant increase of serum creatinine and urea concentrations reflects the severity of renal insufficiency, which occurred in association with the sudden fall in GFR. GM is known to be actively transported into proximal tubules after glomerular filtration in a small proportion where it causes proximal tubular injury and abnormalities in renal circulation that leads to a reduction of GFR [7,27]. These alterations in biochemical parameters were correlated with the renal 
histological lesions: tubular clarification, mesangial expansion and swelling (Fig. 1.GM). Extracts and silimaryn reversed the altered parameters, demonstrating their ability to protect renal function. Normalization of biochemical parameters was associated by significant $(\mathrm{p}<0.01)$ reduction of relative kidney weight and reduction of signs of kidney damage (Fig. 1. AE100 and AE200).

In this study, GM $(80 \mathrm{mg} / \mathrm{kg})$ significantly $(\mathrm{p}<0.05)$ increased the serum sodium level, while chloride level was non-significantly $(\mathrm{P}>0.05)$ increased and, potassium concentration was non-significantly decreased $(\mathrm{P}>0.05)$. Several experimental studies have shown that GM inhibits cell membrane transporters of brush border and dysfunction of co-transport systems and channels, leading to increase absorption of electrolytes [28]. Therefore, the increase in the serum sodium concentration observed in nephrotoxic group might be attributed to the inhibition of transporters by gentamicin. Gentamicin is also known to cause the simultaneous inhibition of very different membrane protein species including $\mathrm{Na}^{+} / \mathrm{K}^{+}$ATPase and released lactate dehydrogenase, resulting in an apparently multifactorial cell death process [29]. A decrease of potassium concentration could be due to either diminished potassium uptake via the Na-K/ATPase or to an enhanced efflux caused by increased potassium membrane permeability or depolarization of the cell electrical potential [30]. Such a depolarization could also explain the observed rise of chloride concentration. Treatment with $C$. diffusa extract restored electrolytes levels; this means that $C$. diffusa extracts could restored the membrane proteins transporter leading to reduced reabsorption of electrolytes.

In recent years, increasing interest is seen in the role of free radicals and oxidative damage in a variety of human diseases [31]. In this respect, several studies have been reported that oxygen-free radicals are considered as important mediators of GM induced renal failure since these chemicals species have a potential to oxidize biomolecules such as proteins, DNA and lipids $[32,33]$. As report in table 5, the GM $(80 \mathrm{mg} / \mathrm{kg})$ significantly $(\mathrm{p}<0.01)$ increased the level of malondialdehyde (MDA) when compared to normal control group. The same result was obtained by Aiswarya et al. [34], using the GM $(80 \mathrm{mg} / \mathrm{kg})$ for eight days. MDA is the end product of lipids peroxidation [35]; So, it increase is used as an indicator of lipid peroxidation, and subsequently oxidative stress. Aqueous and methanolic extracts of $C$. diffusa has prevented against GM- induced lipid peroxidation by a significant decrease of the level of MDA. Lipids peroxidation inhibition potential of the extracts could be due to presence of flavonoids in the plant. Indeed, the studies of Ahem [15] and Malarvizhi [16] have shown that $C$. diffusa contain high proportion of this compound. Flavonoids have been reported to inhibit lipid peroxidation in the cell membrane and improved their integrity against lyses by binding to the membrane [36].

SOD, CAT and GSH are endogenous enzymatic antioxidants which protect the cells components against free radical attack [35]. SOD is the key defence enzyme that catalyses the conversion of superoxide radical to oxygen and peroxides [37]. Peroxide is then transformed by CAT into water and oxygen with the action of GSH. The mechanism of nephrotoxicity of GM involves a decrease of these endogenous enzymatic antioxidants. Our study reveals that GM $(80 \mathrm{mg} / \mathrm{kg})$ significantly $(\mathrm{p}<0.05)$ decreased the SOD and CAT activities and the level of GSH. Similar results were obtained by Ashish et al. [25]. The results showed that enzymatic activities of SOD, CAT and GSH were significantly $(p<0.05$ to $p<0.001)$ increased in groups treated with extracts and silymarin showing their antioxidant effects.

The nephroprotective activity of $C$. diffusa extracts and silymarin were correlated with the histological analysis (Fig.1) and total protein level. Protection of the structure of glomerulus and renal tubules with the aqueous extract of $C$. diffusa and silymarin provides a direct evidence for their nephroprotective activity. In the other hand, the significant increase of TP in $C$. diffusa treated groups suggests their regenerative properties.

\section{CONCLUSION}

The results of the present study indicate that $C$. diffusa extracts provide adequate protection against gentamicin-induced nephrotoxicity. This nephroprotective effect was found to be in a dose dependent manner. The beneficial effects of $C$. diffusa extracts suggested by biochemical findings and supported by histological evidence in this study on gentamicin-induced renal damage might be due to scavenging effect of extracts. This provides persuasive evidence and supports the use this plant in traditional medicine for the treatment of renal disorders.

\section{REFERENCES}

1. Blandy, J., \& Sedky, M. (1995). Lectures notes on urology publications of the Arab center for medical literature and Islamic Organization for Medical Science. Kuwait.

2. Wang, H., Naghavi, M., Allen, C., Barber, R.M., Bhutta, Z. A., Carter, A. (2016). Global, regional and life expectancy, all cause mortality and causespecific mortality for 249 causes of death, 19802015: a systemic analysis for the Global Burden of Disease study 2015. Lancet, 388(10053), 1459544.

3. Srivastava, R., \& Srivastava, P. (2018). Hepatotoxicity and the role of some herbal hepatoprotective plants in present scenario. GJ Dig Dis, 3(2), 2. 
4. Balakumar, P., Rohilla, A., Thangathirupathi, A. (2010). Gentamicin induced nephrotoxicity: Do we have a promising therapeutic approach to blunt it? Pharmacological Research, 62, 179-186.

5. Mingeot-Leclercq, M. P., Glupczynski, Y., \& Tulkens, P. M. (1999). Aminoglycosides: activity and resistance. Antimicrobial Agents Chemotherapy, 43(4), 727-37.

6. Li, J., Li, Q. X., Xie, X. F., Ao, Y., Tie, C. R., Song, R. J. (2009). Differential roles of Dihydropyridine Calcium Antagonist Nifedipine, Nitrendipine and Amlodipine on Gentamicin Indused Tubular toxicity in rats. European Journal of Pharmacology, 620, 97-104.

7. Randjelovic, P., Veljkovic, S., Stojiljkovic, N., Sokolovic, D., Llic, I. (2017). Gentamicin Nephrotoxicity in Animals: Current Knowledge and Future Perspectives. EXCLI Journal, 16, 388399.

8. Pedraza-Chaverri, J., Maldonado, P. D., MedinaCampos, O. N., Olivares-Corichi, I. M., GrandosSilvestre, M., Hernandez-Pando, R. (2000). Garlic ameliorates gentamicin nephrotoxicity: relation to antioxidants. Free Radical Biological Medicine, 29, 602-611.

9. Choi, S. B., Park, C. H., Choi, M. K., JUN, D. W., \& PARK, S. (2004). Improvement of insulin resistance and insulin secretion by water extracts of Cordyceps militaris, Phellinus linteus, and Paecilomyces tenuipes in $90 \%$ pancreatectomized rats. Bioscience, biotechnology, and biochemistry, 68(11), 2257-2264.

10. Faden, R. (2006). "Commelina diffusa", in Flora of North America Editorial Committee, eds.1993; Flora of North America online, 22, New York \& Oxford: Oxford University Press.

11. Wansi, S.L., Kamdem, D.S., Atsamo, A. D., Akoue, R. N., Nguelefack-mbuyo, E. P. (2014). Diuretic activity and toxicological assessment of the aqueous extract from the aerial part of Commelina diffusa in rats. Pharmacologia, 5(5), 184-190.

12. Khan, M. A., Islam, M. T., Rahman, M. A., \& Ahsan, Q. (2011). Antibacterial activity of different fractions of Commelina benghalensis L. Der Pharmacia Sinica, 2(2), 320-326.

13. Sule, O. J., \& Arhoghro, M. E. (2016). Protective potentials ofBryophyllum pinnatum in Wistar albino rats against gentamicin-induced biochemical injury. Journal of Medical and Biological Science Research, 2(10), 163-167.

14. Prima, A. A., Ahmed, R., Faruk, A., Zafroon, Z., \& Dash, P. R. Pharmacological importance of commelina diffusa (COMMELINACEAE): A.

15. Mou, R. A. (2017). Phytochemical and biological investigation of commelina diffusa.

16. Malarvizhi, D., Karthikeyan, A. V. P., Sudan, I., \& Satheeshkumar, R. (2019). Phytochemical analysis of Commelina diffusa Burm. F. through GC-MS method. Journal of Pharmacognosy and Phytochemistry, 8(1), 376-379.

17. Shamim, S., Rana, M. A., Arshad, N., Kumar, A., \& Islam, C. N. (2018). Evaluation of Nephroprotective Effect of Ethanolic Extract of Leaves of Aloe barbadensis against Gentamicin Induced Nephrotoxicity in Rats. Clin Res, 4(4), 7073.

18. Saleem, M., Javed, F., Asif, M., Kashif Baig, M., \& Arif, M. (2019). HPLC Analysis and In Vivo Renoprotective Evaluation of Hydroalcoholic Extract of Cucumis melo Seeds in GentamicinInduced Renal Damage. Medicina, 55(4), 107.

19. Chinnala, K. M., Vangala, V. L., Achanta, P., Mohan, M. E. (2017). Evaluation for nephroprotective activity of ethanolic extract of Allium cepa Linn. In gentamicin-induced nephrotoxicity in rats. Asian Journal of Pharmacy and clinical Research, 10(3), 356-359

20. Chullanandana, K. (2011). Nutritive value of Commelina diffusa as protein source for ruminants. SAADC 2011 strategies and challenges for sustainable animal agriculture-crop systems, Volume III: full papers. Proceedings of the 3rd International Conference on sustainable animal agriculture for developing countries, Nakhon Ratchasima, Thailand, 26-29 July, 2011.

21. Murro, J. K., Muhikambele, V. R. M., \& Sarwatt, S. V. (2003). Moringa oleifera leaf meal can replace cottonseed cake in the concentrate mix fed with Rhodes grass (Chloris gayana) hay for growing sheep. Livestock Research for Rural Development, 15(11), 1-4.

22. Shaheen, U., Manzoor, Z., Khaliq, T., Kanwal, A., Muhammad, F., Hassan, I.J., Shaukat, H M., Mazhar-ul-Haq, M. (2014). Evaluation of Nephroprotective Effects of Foeniculum vulgare Mill, Solanum Nigrum Linn and their Mixture against Gentamicin-induced Nephrotoxicity in Albino Rabbits. International Journal of Pharmaceutical Science Review and Research, 25(1), 1-9.

23. Supriya, G. R., Lalitha, P.R., Gaddam, R.R., Dyaga, V.C. (2015). Evaluation of nephroprotective activity of the methanolic extract of Phyllanthus niruri (Family Euphorbiaceae). International Journal of Pharamceutical and Phytopharmacological Research, 4(5), 276-280.

24. Kumar, P.G., Gautam, V., Mani, S. T., Pal, Y. S., Shetty, H. L. R. (2019). Effect of Withania somnifera on gentamicin induced renal lesions in rats. Revista Brasileira de Farmacognosia, 29(2), 234-240.

25. Ashish, J. S., Ganeshpurkar, A., Pandey, V., Bansal, D., Dubey, N. (2016). Protective Effect of Trichosanthes dioica Extract against Gentamicin Induced Nephrotoxicity in rats. Pharmacognosy Communication, 6(1), 23-27

26. Hamad, E. M., Hassan, M. M., Ihab. S. A., Ahmed, M. Abdel-Salam. (2018). Nephroprotective Effect 
of Camel Milk and Spirulinaplatensis in Gentamicin-Induced Nephrotoxicity in Rats. International Journal of Pharmacology, 14(4), 559565.

27. Sharma, U. S., Kumar, A. (2010). Therapeutic efficacy of rubuselli pticus (smith) fruits extracts in acute acetaminophen induced nephrotoxicity in rats. Pharmacologyonline, 3, 514-524.

28. De Castro, B. B., Colugnati, F. A. B., Cenedee, M. A. (2014). Standardization of renal function evaluation in Wistar rats (Rattus norvegicus) from the Federal University of Juiz de for a's colony. Journal of Brasileiro de Nefrologia, 36(2), 139149.

29. Chaudhary, S. J. and Paranjape, N. A. (2014). Histopathological Evaluation of Nephroprotective Effect of TrichosanthesdioicaRoxb. On Gentamicin Induced Nephrotoxicity in Wistar Rats by Colorimerty and Spectrophotometry. American Journal of Advanced Drug Delivery, 2(1), 022-038.

30. Matsuda, O., Beck, F. X., Dörge, A., \& Thurau, K. (1988). Electrolyte composition of renal tubular cells in gentamicin nephrotoxicity. Kidney international, 33(6), 1107-1112.

31. Lakshmi, B. V. S., \& Sudhakar, M. (2010). Protective effect of Zingiber officinale on gentamicin-induced nephrotoxicity in rats. Int $J$ Pharmacol, 6(1), 58-62.

32. Al-Yahya, M. A., Mothana, R. A., Al-Said, M. S., Al-Dosari, M., Al-Sohaibani, M., Parvez, M. K., \& Rafatullah, S. (2015). Protective effect of citrus medica'otroj'extract on gentamicin-induced nephrotoxicity and oxidative damage in rat kidney. Digest Journal of Nanomaterials \& Biostructures (DJNB), 10(1).

33. Ahmad, F., Al-Subaie, A. M., Al-Ohali, A. I., \& Mohammed, A. S. (2018). Phytochemical and Nephroprotective Activity of Eclipta prostrata against Gentamicin Induced Nephrotoxicity in Wistar Rats. International Journal of Pharma Research and Health Sciences, 6(2), 2559-64.

34. Aiswarya, N., Chandran, V., Teerthanath, S., \& Rakesh, K. B. (2018). Nephroprotective effect of aqueous extract of Pimpinella anisum in gentamicin induced nephrotoxicity in wistar rats. Pharmacognosy Journal, 10(3).

35. Hussain, T., Gupta, R. K., Sweety, K., Eswaran, B., Vijayakumar, M., \& Rao, C. V. (2012). Nephroprotective activity of Solanum xanthocarpum fruit extract against gentamicininduced nephrotoxicity and renal dysfunction in experimental rodents. Asian Pacific journal of tropical medicine, 5(9), 686-691.

36. Benedet, J. A., \& Shibamoto, T. (2008). Role of transition metals, $\mathrm{Fe}$ (II), $\mathrm{Cr}$ (II), $\mathrm{Pb}$ (II), and $\mathrm{Cd}$ (II) in lipid peroxidation. Food chemistry, 107(1), 165-168.

37. Acharya, C. R., Thakar, H. N., \& Vajpeyee, S. K. (2013). A study of oxidative stress in gentamicin induced nephrotoxicity and effect of antioxidant vitamin $\mathrm{C}$ in Wistar rats. National Journal of Physiology, Pharmacy and Pharmacology, 3(1), 14-20. 